\title{
Geographical features of investment activity in Stavropol Krai
}

\author{
Completed with support from Russian Foundation for Basic Research, Grant 16-36-00095 \\ mol_a
}

\author{
Lilia Korneva \\ Department for Socio-Economic Geography, \\ Geoinformatics \& Tourism \\ North-Caucasus Federal University \\ 355000, Stavropol, Russia \\ liliya.cstp@gmail.com \\ Vitaly Belozerov \\ Department for Socio-Economic Geography, \\ Geoinformatics \& Tourism \\ North-Caucasus Federal University \\ 355000, Stavropol, Russia
}

\author{
Natalia Schitova \\ Department for Socio-Economic Geography, \\ Geoinformatics \& Tourism \\ North-Caucasus Federal University \\ 355000, Stavropol, Russia \\ Rakim Mahmudov \\ Department for Socio-Economic Geography, \\ Geoinformatics \& Tourism \\ North-Caucasus Federal University \\ 355000, Stavropol, Russia
}

\begin{abstract}
The article focuses on the study of territorial features of the regional investment activity, whereas the Stavropol Krai is used as the example. The main objective is to identify the specifics of the effect of intra-regional factors on attraction and investment placement. The study is based on the author's database "Investment projects of the Stavropol Krai", compiled based on data from official websites of the local regional authorities. The analysis of the location of investment projects is based on comparison of their geography and industrial affiliation with the territorial and sectoral structure of the economy existing in the region. The study shows that at the intraregional level, there is a link between the territorial and sectoral structure of investments, the horizon of their planning, the total amount of funds and the likelihood of implementing investment projects and their placement in the local system. In the Stavropol Krai, investments typically tend to locate around the major transport routes, sales markets and the major elements of the local economy; their industry affiliation corresponds to the specialization of the industrial center or lies at the junction of related industries. When planning the placement of investment projects, the demographic features of the territory are not taken into account, which contributes to the strengthening of labor migration processes and violates the demographic stability of the area.
\end{abstract}

Keywords - investment, geography of investment, territorial structure of investments, Stavropol Krai, regional economy

\section{INTRODUCTION}

In a market economy, investments not only become a key factor in the success of the local development, but also turn into an important tool for managing it. Investments are relevant to the most diverse spheres of society and reveal specific features of placement and development. Investments, while playing an essential role in the functioning and development of the regional economy, have an impact on public production and employment, as well as promote structural shifts in the development of industries and various spheres of economy. In this regard, the analysis of the spatial aspects of investment processes becomes of paramount importance.

The aim of the article is to identify the territorial features of the investment activity and to reveal the specifics of the effect that intra-regional factors have on attraction and investment in the post-Soviet period, base on the example of the Stavropol Krai.

The work relies on classical theories of a territorial organization of society, as well as studies of investment features and regional development (V.L. Baburin [1], P.Ya. Baklanov [2], M.D. Goryachko [3, 4], A. Kuznetsov [5], P. Krugman [6], P.M. Polyan [7], M.E. Porter [8], A. Shakhnazarov [9] and others).

The database for the research comes from official data, provided by the Regional Committee for Public Statistics; materials from the Agency for Strategic Initiatives; data of the relevant ministries and departments of the Stavropol Krai; the database "Investment projects of the Stavropol Krai", developed by the authors on the basis of information taken from official websites of the regional public authorities.

\section{EXPERIENCE OF STUDYING INVESTMENT PROCESSES IN GEOGRAPHY}

The study of the territorial and spatial structure of investments in geographic science comes both as full-scale studies and as a part of works on Economics \& Geography. Recognizing the importance and significance of investments in 
the region's economy, geographers have adopted the term "investment-geographic position", used to denote a component of the economic and geographical situation, which refers to the position of the region in relation to large industrial and financial centers that can become sources of direct and real investment. They also proposed a methodology for accounting for such situation of a territory when it is possible to forecast the volume and quality of investment, based on the method of energy-production cycles. The theory of investment activity of the territory is also formulated, which implies the presence of the following parts in the territorial system: investment foci, nuclei, centers and belts [10].

Geographical study of investment processes includes analysis and evaluation of parameters for investment development [11, 12], such as investment climate [13, 14], potential and risk, as well as the spatial [15, 16, 17] and sectoral [18] structure of national and foreign investments at various territorial levels, as well as identifying factors that affect investment processes [19]. As a rule, geographic studies attempt to determine the role and place of investment in the regional development, the degree of their influence on the socio-economic processes of the territory [20, 21], as well as the search for mechanisms for managing the investment process.

The key problem, which is relevant for geographers, studying the economic category of investment, is the following contradiction: the main goal of capital investments in the economy of a territory is to generate profit, while the main objective for the territory is sustainable development leading to an increase in the population's well-being accompanied by preserving the environment, which may be violated through promotion of investment processes. Thus, in a broad sense, the main task for geographers is to study the methods for coordinating the goals of the "agents of production" and the territorial social systems [10].

In terms of territorial coverage, studies that cover the entire country $[14,18]$ or a region $[12,21 ; 22 ; 23]$ prevail. The study of investment cooperation between states and regions is particularly common. At the same time, very few works have been carried out at the intra-regional level (except for Western Siberia with its areas rich in oil and gas, and the industrially developed region along the Volga River). Studies focusing on local issues are extremely rare [24]. Point analysis of investment processes is typically associated with the experience of cities in running major investment projects or holding large-scale federal events (the Olympics, the Universiade, the World Cup, the international economic forum, etc.). Research efforts are mainly focused on discussing the transformation processes in financial and economic systems and almost never deal with the analysis of territorial shifts in capital investment and concentration of fixed assets.

The most popular area of geographic research is the study of foreign direct investment in large industries and the activities of transnational companies [18, 25, 26].

The main methods of geographic study of investment are graphic, cartographic, comparative-geographical, expert evaluation, economic-statistical, mathematical simulation, integral coefficients development, classification and typologies, systemic, cause-and-effect and rating analysis, historical and geographical methods. Geographers have made it traditional to compile integral ratings of investment development (investment attractiveness) of regions with the identification of a certain "investment landscape" of the country [21]. Some unique methods for categorizing regions by types of investment activity have also been developed [10, 27].

\section{RESULTS AND DISCUSSION}

The Stavropol Krai is a region in the South of the European part of Russia. It is located between the highland republics and flat, mainly Russian-speaking regions. The Stavropol Krai features the agrarian-industrial orientation of its economy. The main branches of the economy include food and chemical industry, electric power industry, agriculture, construction, trade and catering, tourism and recreation [28]. Industrial production is spread across the cities of the region, while the major concentration can be found in its western and southern parts, where the largest urban areas are located and the transport infrastructure is well developed. Despite the fact that the region ranks 4th in the quality of agricultural land in Russia, it has a significant differentiation of its territory in terms of the agricultural usability degree - from the most favorable lands in the south-western part of the region to risky-for-farming areas in the eastern part. The southern part of the region has unique tourist and recreational resources. The structure of the economy here is based on the radial-ring structure, formed by an industrial hub in the west, a group of industrial centers and transport routes of various significance. Support in the periphery of the region is due to industrial areas, which are also located on federal and regional highways.

This study, based on a dynamics analysis of the investment process in the regions, showed that the Stavropol Krai is the type of "stable middle": its position in terms of investment in fixed assets, as well as per capita investment in 1990-2012 remained basically unchanged. [27]

The structure of investments in the fixed capital of the Stavropol Krai for the period of 2006-2012 has undergone significant transformation: the funding for the transport and communication sphere has been cut by half, and almost completely in real estate. Investments in agriculture, energy production, natural gas and water, as well as construction, have increased slightly, but their overall share is low. An increase has been observed in the investment in the social sphere, public administration and defense. At the same time, the structure of GRP is also changing: the share of agriculture, electricity, gas and water production, transport and communications has declined, while the shares of construction, trade, government and defense have grown. The structure of goods and services shipped has revealed an increase in the share of production of foods and metallurgical goods, whereas the production of coke-fuel and petroleum products, vehicles and equipment has gone down. [27, 30]

An analysis of investment projects in Stavropol Krai showed (fig.1) that half of 172 investment projects are aimed 
towards the development of the industrial sector of the economy, including agro-industrial production, one-fourth for the development of agriculture, and 15 percent for the development of consumer services (which is a rather low indicator for a unique ecological resort area) and a small part is related to the development of the region's infrastructure [29].
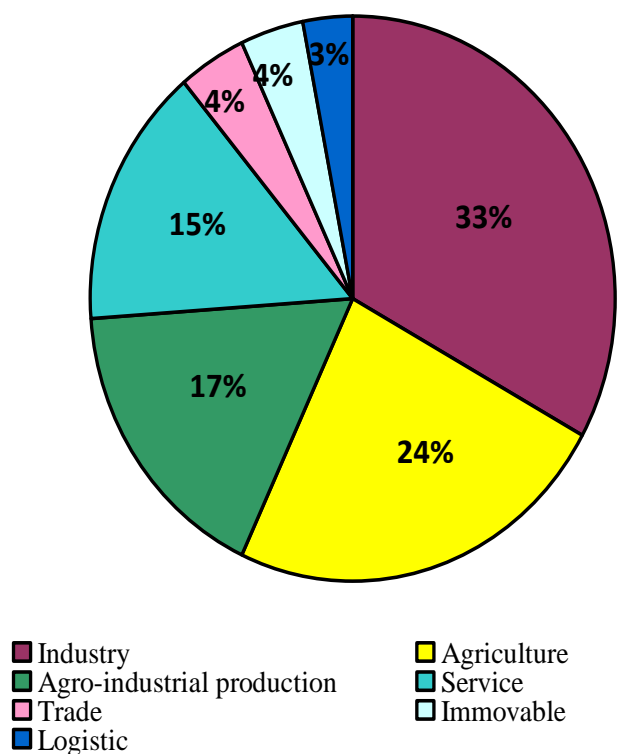

Fig.1 The structure of investments in the sectors of the economy in the Stavropol kray

A total of 19 investment projects have been implemented in the region, mainly in the cities of the southern part of the province and at the industrial complex. The completed investment projects in the field of agriculture and agribusiness were not numerous, had a low cost and revealed a local nature regarding the development of the sectoral structure of the regional economy. The largest projects were directed to the development of tourism, oil \& gas and chemical industry. Most of the implemented projects were linked to the specifics of the region, mostly being aimed at increasing the volume of production and (or) provision of services, but not at deepening the specifics with an expansion of the range of services or goods.

TABLE I. MAJOR INDICATORS FOR THE INVESTENT PROJECTS COMPLETED IN THE STAVROPOL KRAI [29]

\begin{tabular}{|l|l|l|l|}
\hline \multicolumn{1}{|c|}{ Project name } & $\begin{array}{c}\text { Cost, RUR, } \\
\text { mln }\end{array}$ & $\begin{array}{l}\text { Period of } \\
\text { impleme } \\
\text { ntation }\end{array}$ & \multicolumn{1}{|c|}{$\begin{array}{c}\text { Sector of } \\
\text { economy }\end{array}$} \\
\hline $\begin{array}{l}\text { Construction of oil } \\
\text { pumping stations }\end{array}$ & 11000000 & $\begin{array}{l}2012- \\
2014\end{array}$ & $\begin{array}{l}\text { Industry } \\
\text { (oil and gas) }\end{array}$ \\
\hline $\begin{array}{l}\text { Construction of a } \\
\text { shopping and } \\
\text { entertainment center }\end{array}$ & 1000000 & $\begin{array}{l}2013- \\
2014\end{array}$ & Trade \\
\hline $\begin{array}{l}\text { Reconstruction of the } \\
\text { sanatorium-and-spa } \\
\text { complex Rus }\end{array}$ & 1000000 & $2009-$ & Tourism \\
\hline \begin{tabular}{l} 
Technical update of \\
\hline
\end{tabular} & 2000 & 2014 & \\
\hline
\end{tabular}

\begin{tabular}{|c|c|c|c|}
\hline $\begin{array}{l}\text { production of weak } \\
\text { nitric acid with } \\
\text { replacement of units }\end{array}$ & & 2015 & (chemical) \\
\hline $\begin{array}{l}\text { Reconstruction of the } \\
\text { sanatorium } \\
\text { Elbrus }\end{array}$ & 640 & $\begin{array}{l}2007- \\
2013\end{array}$ & Tourism \\
\hline $\begin{array}{l}\text { Capacity increase for } \\
\text { the production of } \\
\text { aluminum cylinders }\end{array}$ & 540 & $\begin{array}{l}2013- \\
2014\end{array}$ & $\begin{array}{l}\text { Industry } \\
\text { (chemical), } \\
\text { mettalurgy }\end{array}$ \\
\hline $\begin{array}{l}\text { Construction of a } \\
\text { residential complex } \\
\text { with commercial and } \\
\text { administrative premises } \\
\text { and hotel rooms }\end{array}$ & 250 & $\begin{array}{l}2012- \\
2014\end{array}$ & Tourism \\
\hline $\begin{array}{l}\text { Construction of the } \\
\text { shopping center Lira }\end{array}$ & 220 & $\begin{array}{l}2012- \\
2015\end{array}$ & Trade \\
\hline $\begin{array}{l}\text { Construction of a } \\
\text { rehabilitation } \\
\text { balneological center }\end{array}$ & 160 & $\begin{array}{l}2012- \\
2014\end{array}$ & Tourism \\
\hline $\begin{array}{l}\text { Reconstruction and } \\
\text { equipment update for } \\
\text { raising hens }\end{array}$ & 167 & $\begin{array}{l}2013- \\
2014\end{array}$ & $\begin{array}{l}\text { Agriculture } \\
\text { (poultry } \\
\text { breeding) }\end{array}$ \\
\hline $\begin{array}{l}\text { Expansion of car-fleet } \\
\text { for a plant involved in } \\
\text { the production of } \\
\text { concrete }\end{array}$ & 153 & 2014 & $\begin{array}{l}\text { Industry } \\
\text { (construction) }\end{array}$ \\
\hline $\begin{array}{l}\text { Construction } \\
\text { (reconstruction) of the } \\
\text { shopping } \\
\text { Vershina }\end{array}$ & 100 & $\begin{array}{l}2013- \\
2014\end{array}$ & Trade \\
\hline $\begin{array}{l}\text { Development of high- } \\
\text { tech production of } \\
\text { plastics }\end{array}$ & 60 & $\begin{array}{l}2013- \\
2014\end{array}$ & $\begin{array}{l}\text { Industry } \\
\text { (chemical) }\end{array}$ \\
\hline $\begin{array}{l}\text { Warehouse } \\
\text { construction for } \\
\text { household chemistry }\end{array}$ & 60 & $\begin{array}{l}2013- \\
2014\end{array}$ & $\begin{array}{l}\text { Trade, } \\
\text { logistics }\end{array}$ \\
\hline $\begin{array}{l}\text { Construction of } \\
\text { vegetable storage with } \\
\text { an operational storage } \\
\text { facility for } 7 \text { thousand } \\
\text { tons of fresh vegetables }\end{array}$ & 45 & $\begin{array}{l}2013- \\
2015\end{array}$ & $\begin{array}{l}\text { Agribusiness } \\
\text { and logistics }\end{array}$ \\
\hline $\begin{array}{l}\text { Construction of a } \\
\text { family farm for } 50 \\
\text { heads of dairy cattle }\end{array}$ & 36 & $\begin{array}{l}2013- \\
2014\end{array}$ & $\begin{array}{l}\text { Agriculture } \\
\text { (cattle } \\
\text { breeding) }\end{array}$ \\
\hline $\begin{array}{l}\text { Construction of the } \\
\text { health complex Valley } \\
\text { of Geysers }\end{array}$ & 30 & $\begin{array}{l}2014- \\
2015\end{array}$ & Tourism \\
\hline $\begin{array}{l}\text { Construction of a } \\
\text { sewing workshop }\end{array}$ & 21 & $\begin{array}{l}2012- \\
2014\end{array}$ & $\begin{array}{l}\text { Industry } \\
\text { (consumer } \\
\text { goods) }\end{array}$ \\
\hline $\begin{array}{l}\text { Construction of a } \\
\text { fattening complex for } \\
50 \text { heads of cattle }\end{array}$ & 5 & $\begin{array}{l}2014- \\
2015\end{array}$ & $\begin{array}{l}\text { Agriculture } \\
\text { (cattle } \\
\text { breeding) }\end{array}$ \\
\hline
\end{tabular}

The bulk of the planned investment projects in the western part of the Stavropol Krai is related to industrial development, in the east - to the agribusiness, except for the territories of extraction and processing of hydrocarbon raw materials; in the southern part the prevailing investment projects are of recreational, medical and infrastructural type.

An absolute majority of investment projects, regardless of their industrial affiliation, have been planned for implementation in the agglomerations of the southern and western parts of the Stavropol Krai, where a significant proportion of the population is concentrated and the transit transport infrastructure is developed. This testifies to the primary attraction of the new business to the consumer, labor 
resources and federal transport highways, which allows making the following assumption: in the market conditions, consumer demand attracts an investment demand. More than half of the investment projects are based in urban settlements, which indicates the unimportance of the land rent factor at the planning stage. The land resources, needed for the implementation of projects in the area of agriculture and agribusiness, are typically decisive for the location of such projects subject to the specialization of the area.

The large investment projects in the field of animal husbandry include the planned development of the Eastern Agrocomplex, the construction of a dairy farm, breeding grounds for chicken, the construction of pig feeders, and greenhouses.

Investment projects in the processing sector (except for construction materials and electric power industry) are associated with the predominant development of urban areas, as well as district centers. There are plans to establish an agroindustrial cluster, to construct two sugar plants, an industrial park of the regional level, a dairy plant, a cannery, and the largest poultry processing facility.

The development of the construction materials' industry is related to large deposits of construction materials and is associated with the implementation of projects for the construction of a steel plant to manufacture reinforcement, a plant for the production of aerated concrete, ceramic facing bricks, glass-magnesite plates, and a cement plant.

Significant investments are expected in the industry typical of the Stavropol Krai in the south of Russia - electric power industry, as well as engineering and chemical industry. It is expected that investment projects, such as the construction of a power plant unit, a solar power station, a hydroelectric power plant, an automobile plant, a polymer plant, a facility for producing disposable tableware, production of high-tech medical products, an inulin and fructose plant, and a facility to produce fiberglass pipes will be implemented.

According to the existing investment projects, the major tourism centers of the Stavropol Krai will remain the Caucasus Mineral Waters (recreational and health tourism), as well as a number of eastern areas (hunting and fishing, healthimproving, ethnic tourism) and the suburbs of the Stavropol agglomeration (extreme and weekend tourism).

The labor potential of a number of areas is not used efficiently, which leads to the migration of people in their working age in search of work, and the concentration of the population around the region's leading economic centers. As a result, there is an increasing socio-economic polarization between the developed, labor affording and depopulating, economically lagging behind areas.

An analysis of the planned timeframe for the investment projects shows that the average planning horizon in the region is low -3 years. Only 2 areas proved to be attractive enough for long term investment development (more than 10 years) the construction of a facility to produce ethylene and its derivatives from the North Caspian natural gas, as well as growing fruits, berries and horticulture in enclosed soil, including the development of an intensive garden with high- technology maintenance. Only 11 projects $(6 \%)$ are designed as mid-term; they are related to the major elements of the local economy in the Stavropol Krai. These projects offer investors mid- and long-term planning due to their being stable-in-time elements in the regional economy, with access to an established transport network, respectively concentrated labor resources, and potential consumer demand.

For the development of the Stavropol Krai, 12 regional industrial parks have been established [29]. All of them are located in cities, which are considered by the authorities as poles and centers of growth. Comparing the territorial structure of the regional industrial parks with the areas of investment projects concentration in the region suggests their irrational planning: a number of areas of investment projects' concentration have been removed from the regional industrial parks, while some neighboring parks have similar specialization. A highly specialized park has been designed, which does not imply the development of associated industries and the availability of a large number of residents.

An analysis of the modern territorial structure of the Stavropol Krai's economy has made it possible to identify problematic areas in the chain of "production-processingconsumption".

First, this is an incomplete use of resources for the development of the construction materials industry. The problem is related to the specifics of the consumer placement - the most active construction is underway in the western and central regions of the Stavropol Krai, where the enterprises of the construction complex are located.

Second, through the entire period of sheep breeding development in the region, a complex for processing wool and producing textile products has not been established, while raw materials for this sub-sector are available in sufficient quantity and of high quality.

Third, the western and northern regions of the Stavropol Krai, have already developed an area for growing vegetables; however, there are some issues with storage and processing of vegetables since there is no respective infrastructure and enterprises in the area. At the same time, the vegetablegrowing cluster that is being developed can increase the competitive advantages of the regional economy both in the south of Russia and within the framework of the integrated programs for ensuring the national food security.

Fourth, the new actively developing zone for industrial crops cultivation - the western part of the region - is not provided with a sufficient number of the respective processing enterprises. The only sugar factory in the area does not have enough capacity to process the existing volume of sugar beet, due to which manufacturers of this product are forced to deliberately reduce the volume of its production to reduce the risks of having the product unsold.

The potential changes identified in agriculture, industry and transport explain the need for newer programs aimed at the development and support of the regional periphery and the areas remote from the major highways. The region's investment development must comply with these programs and be based on the principles of public-private partnership to 
impose balance on the interests of the region along with those of investors.

The development of the urbanized areas of the Stavropol Krai should be carried out through diversification of the economy, strengthening the role of high-tech industries (pharmaceutical industry, chemical industry, nanotechnology). Effective development and preservation of the viability of the urban settlements with a narrowly specific economy can be ensured through programs for the development of singleindustry towns.

The implementation of the planned large investment projects, as the authors view it, will be connected with the major elements of the territorial structure in the region's economy. The investment activity may improve via higher relevance and geographic location of the regional industrial parks with proven mechanisms to decrease the investors' tax base, whereas such incentives need to be approved through the federal legislation.

The proposed large investment projects needs some revision due to their insufficient elaboration and inconsistency with the territorial-sectoral economy structure and economic feasibility.

Success in investment development will largely be related to the infrastructure development. Improved economic and geographical situation of peripheral and uptown municipal areas can be reached through the development of the transport network. In particular, the planned construction of the railway will connect areas in the eastern part of the region with the western one and will offer give direct access to the ports of the Caspian Sea and the international North-South transport corridor, and further, will contribute to the development of the Caspian-Black Sea corridor. The areas of the region, falling into the zone influenced by the new transport system, will acquire higher town-planning and investment attractiveness.

\section{CONCLUSIONS}

The following conclusions could be drawn from the analysis conducted

1) Knowing the areas of territorial population and industry concentration, as well as being aware of the region's logistics structure features, makes it possible to plan the geography and the sectoral orientation of the regional industrial parks more efficiently.

2) Investments tend to be attracted to urbanized, sustainable elements of the regional economy (industrial centers, hubs and points, transport highways of the federal level), concentrating labor resources and revealing a high consumer demand and, as a rule, investments correspond to the local economic focus.

3) Most of the completed investment projects have a low cost and short-term planning horizon, while located in laborabundant areas, linked to local specialization and aimed at increasing production and (or) provision of services, but not deepening the specialization along with expanding the range of services or products.
4) The level of investment depends directly on the area's geographic features and transportion options, which is associated with the manufacturers' striving to minimize transportation costs.

5) Improving the investment activities of the Stavropol Krai would take establishing processing enterprises to operate in areas like construction materials (in the central and western parts of the region), textile industry (in the eastern part), vegetable storage and processing (in the north-western and south-east parts), and industrial crops (in the western part). Establishing a pharmaceutical and chemical cluster in an industrial hub and a transport and logistics complex within the western zone would allow the region to adopt a specialization for the South of Russia and would ensure a steady increase in GRP in the mid-term. To ensure balanced development of the eastern territories, there is a need to ensure their transport access to the most significant city in the eastern part and to establish a well-developed social infrastructure in it.

\section{References}

[1] V.L. Baburin, M.D. Goryachko, "Transformation of city structures during the implementation of a major investment project" (on the example of Sochi-2014), Problems of Geography, vol. 141, pp. 433452, 2016.

[2] P.Ya. Baklanov, Territorial structures of the economy in regional management. Moscow: Science, 2007. 237 p.

[3] M. D. Goryachko, "Potential influence of large-scale investment projects", Regional Research, no. Special Issue, pp. 77-87, 2015.

[4] M. D. Goryachko, "Evaluation of the impact of Russia's major investment projects on the social and economic development of regions", Regional Studies, vol. 4., pp. 88-100, 2014.

[5] A. V. Kuznetsov, Yu.D. Kvashnin, A.A. Nevskaya, A.S. Chetverikova, EAEU and Eurasia: Monitoring and Analysis of Direct Investments, Report \#41, St. Petersburg: EDB Centre for Integration Studies, 2015, 66 p.

[6] M. Fujita, P. Krugman, A.J. Venables, The Spatial Economy: Cities, Regions, and International Trade. Cambridge, MA: MIT Press, 2001, 384 p.

[7] L.I. Vasilevsky, P.M. Polyan, "Territorial structures of the national economy and their parametrization", Izv. AN SSSR, Ser. Geogr., vol. 2, pp. 54-69, 1978.

[8] M.E. Porter, "The Competitive Advantage of Nations", Harward Business Review, pp. 73-93, March-April 1990.

[9] A. Shakhnazarov, I. Roizman, "Investment attractiveness of regions", Investments in Russia, vol. 9, pp. 8-10, 1996.

[10] A.B. Sebentsov. Geograficheskie problemy investicij v hozjajstvennoe razvitie regionov Rossijskogo Severa. Cand, Diss. [Geographical problems of investments in the economic development of the regions of the Russian North. Abstract of the Diss. Cand. Geogr. Sciences]. Moscow, 2007, 15 p.

[11] M.A. Berezhnoy. Vlijanie razmeshhenija investicionnogo proekta na ego jekonomicheskuju jeffektivnost': na primere solodovennogo proizvodstva. Cand, Diss. [Influence of placing an investment project on its economic efficiency: on the example of malt production, Abstract of the Diss. Cand. Geogr. Sciences]. Moscow, 2005, 23 p.

[12] A.E. Lapin, V.A. Makeeva, "Rating evaluation of investment attractiveness of the region" (on materials of the Ulyanovsk region), Izvestiya Saratov University. Series Economics. Control. Right, vol. 13, \# 3 (2), pp. 398-403, 2013.

[13] E.N. Koroleva, Investicionnyj klimat regiona: Jekonomikogeograficheskij analiz. Cand, Diss. [Investment climate of the region: Economic-geographical analysis, Abstract of the Diss. Cand. Geogr. Sciences]. Perm, 2002, 16 p. 
[14] N.N. Loginova, A. Loginova, "Evaluation of the investment climate as a factor determining the level of social and economic development of the region”, Mordovia University Bulletin, vol. 15, \#1-2, pp. 24-29, 2005.

[15] S.S. Lachininsky, Prostranstvennaja differenciacija prjamyh amerikanskih investicij za rubezhom. Cand, Diss. [Spatial differentiation of direct American investments abroad, Abstract of the Diss. Cand. Geogr. Sciences]. St. Petersburg, 2006, 18 p.

[16] A.V. Kuznetsov, "Features of the analysis of the geography of foreign investment of transnational corporations", The Baltic region, vol. 8, \#3, pp. 30-44, 2016.

[17] E.K. Lvova, Territorial'naja struktura investicij kak faktor jekonomicheskogo razvitija KNR. Cand, Diss. [Territorial structure of investments as a factor of economic development of the PRC, Diss. Candidate of Geographical Sciences]. Moscow, 2011, 145 p.

[18] N. A. Kryukova, Geografija prjamyh inostrannyh investicij v gazovuju promyshlennost' Rossii. Cand, Diss. [Geography of foreign direct investment in the gas industry in Russia, Abstract of the Diss. Cand. Geogr. Sciences]. Moscow, 2010, 27 p.

[19] O. S. Ngaeva, "Evaluation of the influence of regional factors on the effectiveness of the investment project", Modern research of social problems (electronic scientific journal), vol. 5 (49), pp. 764-773, 2015.

[20] I.A. Dets, Rol' proektnogo podhoda v territorial'nom razvitii na primere Bajkal'skogo regiona. Cand, Diss. [The role of the project approach in territorial development by the example of the Baikal region, Diss. Candidate of Geographical Sciences]. Irkutsk, 2013,178 p.

[21] V.A. Kozlov, Vlijanie investicij na razvitie i razmeshhenie proizvoditel'nyh sil: na primere promyshlennosti gorodov Samarskoj oblasti. Cand, Diss. [Influence of investments on the development and placement of productive forces: the example of the industry of the cities of the Samara region, Abstract of the Diss. Cand. Geogr. Sciences]. Perm, 2007, 19 p.

[22] I.V. Kudryashova, A.A. Cot, "Foreign direct investment as a factor in the development of the economy of the Volgograd region", Innovations and investments, vol. 21 (300), pp. 11-16, 2013.

[23] S.V. Smagin, "Investment component of the development of the industrial complex of the Orenburg region", Bulletin of the Orenburg State University, vol. 5 (86), pp. 74-77, 2008.

[24] T.D. Degtyareva, E.A. Chulkova, "Investigation of investment activity of municipal regions of the region", Proceedings of the Orenburg State Agrarian University, vol. 2, \# 30-1, pp. 142-145, 2011.

[25] E.A. Fedorova, B.K. Korkmazova, M.A. Muratov, "Evaluation of the efficiency of companies with foreign direct investment: industry specific features in the Russian Federation", Spatial Economics, vol. 2. pp. 4763, 2015.

[26] D.N. Samusenko, "Geographical analysis of the processes of direct investment in the modern world economy, Newsletter of Moscow University, Ser. 5: Geography, vol. 1, pp. 42-48, 2014.

[27] N.A. Shchitova, L.I. Korneva, "Polyscale analysis of investment location in the regions of the European part of Russia in the post-Soviet period", Science. Innovation. Technologies, vol. 1, pp. 175-207, 2017.

[28] A.A. Belozerov, A.N. Panin, R.A. Prikhodko and others, Ethnic atlas of the Stavropol Krai, Stavropol: FOK-South, 2014, 304 p.

[29] Ministry of Economic Develoment for Stavropl Krai, official website. Available at: http://www.stavinvest.ru (accessed 30 July 2017).

[30] Territorial Body of Federal Service for Public Statistics of Stavropol Krai. Ofocial website. Available at: http://www.stavstat.ru (accessed 30 July 2017). 